\title{
KESIAPAN BERWIRAUSAHA PADA SISWA SMK KOMPETENSI KEAHLIAN JASA BOGA
}

\author{
Anggri Sekar Sari \\ Pascasarjana, Universitas Negeri Yogakarta \\ anggri_sekar@yahoo.com
}

\begin{abstract}
ABSTRAK
Abstrak: Kesiapan Berwirausaha pada Siswa SMK Kompetensi Keahlian Jasa Boga. Tujuan penelitian untuk mengungkapkan pengaruh peranan orangtua, ketrampilan pengelolaan UJB, dan self-efficacy terhadap kesiapan berwirausaha. Penelitian menggunakan pendekatan ex post facto. Populasi adalah siswa SMK Kompetensi Keahlian Jasa Boga di DIY. Sampel sebanyak 198 responden ditentukan menggunakan teknik proportional random sampling. Data dikumpulkan dengan instrumen angket dan tes. Analisis data menggunakan statistik deskriptif dan regresi linier berganda. Penelitian menunjukkan kesiapan berwirausaha relatif sedang (30,8\%). Uji hipotesis menemukan bahwa variabel peranan orangtua berpengaruh positif dan signifikan terhadap kesiapan berwirausaha sebesar 0,374 (sig 0,000). Begitu pula ketrampilan pengelolaan UJB sebesar 0,256 (sig 0,000) dan self-efficacy sebesar 0,191 (sig $0,007)$ berpengaruh positif dan signifikan terhadap kesiapan berwirausaha. Terdapat pengaruh secara bersama-sama antara peranan orangtua, ketrampilan pengelolaan UJB, dan self efficacy sebesar 55\% terhadap kesiapan berwirausaha.
\end{abstract}

Kata Kunci: Kesiapan Berwirausaha

\section{THE ENTREPRENEURIAL READINESS OF THE STUDENTS OF THE FOOD \& BEVERAGE SKILL COMPETENCY IN PUBLIC VOCATIONAL HIGH SCHOOLS}

\begin{abstract}
The Entrepreneurial Readiness of the Students of the Food \& Beverage Skill Competency in Public Vocational High Schools in Yogyakarta Spesial Territory.The purposes of this research are to reveal the effect of parents roles, vocational skills in the Food \& Beverage Business Management, and self-efficacy on the entrepreneurial readiness. This study uses the ex post facto approach. The population is the students of the food \& beverage skill competency in public vocational high schools in Yogyakarta Spesial Territory. A sample of 198 respondents is established using the proportional random sampling technique. The data are collected using questionnaires and a test. The data are analyzed using descriptive statistics and using multiple linear regression. The results show that almost half (30.8) of students have a low entrepreneurial readiness. The hypothesis testing shows that the parents roles have a positive and significant effect on the entrepreneurial readiness as much as 0.374 (sig 0.000). Similarly, vocational skills in the Food \& Beverage Business Management and self-efficacy have significant and positive effects on the entrepreneurial readiness as much as 0.256 (sig 0.000) and as much as 0.191 (sig 0.007) respectively The of parents' roles, vocational skills in the Food \& Beverage Business Management, and self-efficacy collectively have the effect of 55 percent on the entrepreneurial readiness.
\end{abstract}

Keyword: Entrepreneurial Readiness 


\section{PENDAHULUAN}

Harapan untuk diterima di dunia kerja tentunya bukanlah suatu kesalahan, akan tetapi tidak dapat dipungkiri bahwa kesempatan kerja sangat terbatas dan tidak berbanding lurus dengan lulusan lembaga pendidikan baik dasar, menengah, maupun pendidikan tinggi. Selain itu, pemerintah diharapkan berupaya melalui kebijakan pendidikan dalam rangka merubah paradigma agar siswa lebih siap berwirausaha dan lulusan tidak hanya menitikberatkan menjadi pegawai.

Banyaknya masyarakat di Indonesia yang ingin menjadi pegawai menjadikan jumlah pengangguran di Indonesia relatif tinggi. Kesenjangan ini merupakan penyebab utama peningkatan angka pengangguran. Sedangkan pengangguran sendiri merupakan salah satu permasalahan pembangunan yang sangat kritis, khususnya di Negara Indonesia termasuk di daerah-daerah pelosok. Berdasarkan data statistik pada Agustus 2011 sebanyak 8, 12 juta orang di Indonesia dengan tingkat pengangguran terbuka sebesar 7,41 persen. Sedangkan di Di Yogyakarta sebanyak 124,4 ribu orang dengan tingkat pengangguran terbuka sebesar 6,02 persen (Badan Pusat Statistik RI, 2011).

Salah satu solusi permasalahan tersebut adalah dengan mencetak lulusan lembaga pendidikan yang memiliki kemampuan dalam mengembangkan ketrampilannya agar memiliki self efficacy yang tinggi dan kedepannya dapat menjadi modal siap dalam berwirausaha. Selain menjadi solusi bagi diri sendiri, berwirausaha dapat berguna bagi orang lain karena memerlukan karyawan pada usaha yang akan dijalankan. Selain itu dapat mengurangi pengangguran di Yogyakarta yang diperkirakan akan semakin meningkat.

Berwirausaha selain dapat mengurangi jumlah pengangguran yang semakin meningkat, bermanfaat dalam meningkatkan kesejahteraan dan devisa negara. Menurut Macke \& Marley (2003), Area economics with high rates of entrepreneurship typically have strong economic performance and higher levels of prosperity. Pernyaataan tersebut menjelaskan bahwa jumlah pengangguran dan kemiskinan dapat diperkecil dengan keberanian membuka usaha-usaha baru atau berwirausaha. Hal ini menunjukkan bahwa wirausaha merupakan potensi yang terbaik salah satunya dalam bidang ekonomi dan pembangunan. Suatu negara akan maju dan stabil perekonomiannya jika penduduk yang menjadi wirausahawan minimal $2 \%$ dari jumlah penduduk (JPPN, 2011).

Semua alasan tersebut yang mendorong seseorang untuk memilih berwirausaha. Akan tetapi, kesiapan berwirausaha masyarakat Indonesia saat ini masih sangat rendah dilihat dari data minat berwirausaha masyarakat Indonesia yaitu $0,18 \%$ dari jumlah penduduk. Namun demikian pada kenyatannya tidaklah mudah memulai suatu usaha. Menurut pengamat pendidikan, Darmaningtyas (2008) dalam Mery (http://pustaka.unpad.ac.id) ada kecenderungan, semakin tinggi tingkat pendidikan semakin besar keinginan mendapat pekerjaan yang aman. Mereka tidak berani ambil pekerjaan berisiko seperti berwirausaha. Selain itu, rasa takut yang berlebihan akan kegagalan dan kerugian karena rasa percaya diri yang rendah menjadikan kesiapan seseorang untuk berwirausaha rendah. Wasty (1999: 100) menjelaskan bahwa orangtua 
berperan dalam mendidik untuk memberikan bekal mental kewirausahaan pada masa kanakkanak dan dilanjutkan pada tahap anak menjadi mampu untuk berwirausaha. Dalam hal ini peranan orangtua sangat penting untuk menumbuhkan sebuah kesiapan dan keberanian untuk berwirausaha. Keberanian untuk memulai merupakan modal utama yang harus dimiliki seseorang untuk terjun dalam dunia usaha. Namun keberanian saja tidak cukup, keberanian tanpa disertai ketrampilan dan kemampuan berwirausaha seringkali menjerumuskan kita dalam kegagalan.

Padahal besarnya peluang berwirausaha khususnya di Yogyakarta dapat diperkuat melalui data Berita Resmi Statistik. Sektor ekonomi Provinsi DIY memiliki peranan terbesar dalam perekonomian bila diukur dari PDRB mengalami kenaikan sebesar 7,96\% dan bila diukur secara kumulatif yaitu 5,14\%. Kenaikan perekonomian tersebut selain dikarenakan adanya peningkatan pada sektor jasa, juga dipengaruhi oleh sektor perdagangan (yang meliputi perhotelan, restoran, dll) (BRS, 2011). Peningkatan pada sektor perdagangan yang meliputi perhotelan, perdagangan maupun usaha jasa boga lainnya dapat menjadi tolak ukur bahwa kewirausahaan di bidang jasa boga masih dapat diandalkan di Yogyakarta dan menjadi peluang. Menurut Andi (Tribun, 2012: 11) salah seorang pengusaha kuliner di Yogyakarta menegaskan bahwa bisnis kuliner di Yogyakarta prospek kedepannya bagus. Terbukti dengan kekayaan kuliner yang ada di Yogyakarta, usaha kuliner masih tetap bertambah dan berkembang. Peluang untuk berwirausaha tersebut dapat digunakan oleh
SMK perhotelan maupun Jasa Boga dalam mengisi dan berperan dalam perkembangan kuliner di Yogyakarta.

Sekolah Menengah Kejuruan (SMK) bertujuan secara umum untuk mempersiapkan peserta didik untuk bekerja dalam bidang tertentu (Fu`adz, 2009: 11-12). Oleh karena itu, SMK merupakan salah satu yang berperan kepada anak didiknya untuk memberikan bekal ketrampilan dan pengetahuan hasil belajar. Hasil belajar yang diberikan oleh SMK, diharapkan agar siswa dapat berwirausaha agar meminimalisir jumlah pengangguran. Akan tetapi ketrampilan siswa saat ini masih kurang dikarenakan proses pembelajaran praktik yang kurang dengan mata pelajaran umum yang relatif banyak dan waktu yang relatif padat.

Menurut Yuli Unggul selaku Humas SMKN 6 Yogyakarta waktu ditemui pada tanggal 24 Oktober 2011 jam 09:10 WIB di ruang tunggu SMKN 6 Yogyakarta, kesiapan berwirausaha siswa masih rendah dikarenakan faktor-faktor mental siswa yang belum matang, kurangnya keyakinan (rasa percaya diri), modal, motivasi, peranan orang tua maupun peranan sekolah yang kurang.

Untuk menciptakan dan meningkatkan kewirausahaan pada siswa SMK maka sangat perlu dilakukan penelitian mengenai kesiapan berwirausaha. Tony Wijaya (2007: 118) menyebutkan beberapa penelitian yang dapat memperkuat pernyataan tersebut, yaitu dalam penelitian Hartini yang mengungkapkan bahwa sampai saat ini diantara lulusan SMK tidak banyak yang berorientasi berwirausaha ditunjukkan dengan hanya 6\% lulusan SLTA dan Perguruan Tinggi yang menekuni wirausaha 
sisanya $94 \%$ memilih menjadi pegawai dan penelitian Sanmustri yang menemukan bahwa siswa SLTA di Yogyakarta masih mempunyai kecenderungan yang lebih kuat untuk menjadi karyawan bahkan pegawai negeri. Lebih lanjut dijelaskan bahwa ada beberapa hal yang mengakibatkan siswa SMK tidak tertarik berwirausaha setelah lulus, dikarenakan tidak berani mengambil resiko, tidak percaya diri, takut gagal, tidak memiliki modal, kurang memiliki motivasi, serta tidak memiliki semangat serta mempunyai keinginan untuk berusaha sendiri. Menjadi wirausaha seringkali dipandang sebagai pilihan karir yang tidak terlalu disukai karena dihadapkan pada situasi keseharian yang tidak pasti, penuh rintangan, dan frustasi berkaitan dengan proses pendirian usaha baru (Campbell dalam Segal, Borgia and Schoenfeld, 2005 dalam Mery (http://pustaka.unpad.ac.id)). Faktor-faktor tersebut mengakibatkan siswa berfikir bahwa berwirausaha merupakan sesuatu yang sulit dilakukan, sehingga siswa lebih senang bekerja pada orang lain dan tidak siap berwirausaha.

Penelitian Anastasia O.K (2007) yang dilakukan pada siswa tingkat III di Gunungkidul menemukan bahwa variabel dominan yang mempengaruhi kesiapan berwirausaha siswa tingkat III adalah variabel pengetahuan kewirausahaan, praktik unit produksi jasa, dan peran keluarga. Sedangkan penelitian yang dilakukan oleh Marsono (2010) pada Mahasiswa Pendidikan Teknik Mesin Fakultas Teknik Universitas Negeri Yogyakarta, menemukan bahwa terdapat pengaruh yang positif antara pengetahuan kewirausahaan, dukungan keluarga, soft skill, dan prestasi belajar terhadap kesiapan berwirausaha.

Hasil penelitian diatas menunjukkan bahwa temuan tentang faktor-faktor yang mempengaruhi kesiapan berwirausaha masih tertuju pada pengetahuan kewirausahaan dan peranan keluarga, sehingga dalam penelitian ini mengkaji faktor-faktor lain yang mempengaruhi kesiapan berwirausaha disamping faktor-faktor tersebut agar dapat mengetahui sejauh mana kesiapan berwirausaha pada siswa. Dengan mengetahui faktor-faktor kesiapan berwirausaha tersebut diharapkan wirausaha di Indonesia, khususnya di Yogyakarta dapat berkembang dalam peningkatan pembangunan dan dapat mengurangi jumlah pengangguran Oleh karena itu, penulis tertarik untuk mengangkat suatu tema kewirausahaan yang berjudul: Kesiapan Berwirausaha Siswa SMKN Kompetensi Keahlian Jasa Boga di DI Yogyakarta.

\section{Kesiapan}

Kesiapan berasal dari kata "siap" yang berarti kecenderungan akan kemampuan (competence) dan kesediaan seseorang untuk melakukan sesuatu (readiness). Menurut Cronbach dalam Wasty (2006:191), kesiapan (readiness) merupakan segenap sifat atau kekuatan yang membuat seseorang dapat bereaksi dengan cara tertentu. Sedangkan Slameto (2010: 113) mendefinisikan bahwa kesiapan adalah keseluruhan kondisi seseorang yang membuatnya siap untuk memberi respon/jawaban dengan cara tertentu terhadap suatu situasi.

Dari beberapa pengertian mengenai kesiapan, dapat dirumuskan bahwa kesiapan merupakan suatu keadaan yang mendorong 
seseorang secara keseluruhan untuk melakukan reaksi (pekerjaan) secara fisik, mental, pengetahuan maupun dengan ketrampilan. Dalam hal ini yang mempengaruhi kesiapan seseorang adalah kematangan, perkembangan keterampilan berpikir, dan adanya motif. Kematangan dapat dikriteriakan sebagai perkembangan fisik dan mental yang sudah matang, ketergantungan terhadap orang tua, dapat memilih tugas dan menyelesaikan tugas sendiri sesuai dengan minat, memiliki prestasi, teratur dalam berfikir dan tingkah laku.

\section{Kewirausahaan}

Istilah entrepreneur (wirausaha) berasal dari bahasa Perancis entreprende yang berarti berusaha atau mengusahakan. Sedangkan entrepreneur dalam bahasa Indonesia dapat diartikan wirausaha yang berasal dari kata 'wira`, memiliki makna sebagai orang yang berani, teladan, utama, atau patut dicontoh, sedangkan usaha yang berarti kerja keras untuk memperoleh hasil atau menghasilkan sesuatu. Sehingga wirausaha adalah seseorang yang mempunyai kreativitas dan semangat yang tinggi untuk bekerja dan berhasil dalam usahanya.

Enterpreneurship is the process of creating something new with value by devoting the necessary time and effort, assuming the accompanying financial, psychic, and social risks, and receiving the resulting rewards of monetary and personal satisfaction and independence (Hisrich, 2008: 8).

Kewirausahaan tersebut dapat diartikan sebagai proses untuk menciptakan sesuatu yang baru oleh nilai dengan mengabdikan waktu dan usaha yang diperlukan, adanya asumsi keuangan yang menyertainya, psikis, risiko sosial, dan mendapatkan penghargaan yang dihasilkan dari kepuasan pribadi.

Sementara itu ciri-ciri pokok yang harus dipersiapkan oleh wirausahawan menurut Wasty (1999: 45) adalah (1) moral yang tinggi, (2) sikap mental wirausaha, (3) kepekaan terhadap lingkungan ketrampilan wirausaha. Sedangkan Sifat-sifat yang harus dipersiapkan dan dimiliki wirausahawan menurut Meredith (2005: 5-6) adalah: percaya diri, berorientasi pada tugas dan hasil, pengambilan resiko, kepemimpinan, keorisinilan, berorientasi ke depan.

Sikap mental yang tepat terhadap suatu pekerjaan ataupun wirausaha sangatlah penting, karena sikap mental yang positif akan merubah pekerjaan menjadi pekerjaan yang menarik dan memberikan kepuasan. Menurut Slameto (2010: 133) seseorang yang secara mental sehat biasanya adalah yang memiliki konsep diri yang positif dan merasa bahwa dirinya berharga.

Kesiapan berwirausaha menurut Mueller (2010) ada tiga kategori umum yang harus dimiliki yaitu kepribadian, ketrampilan, dan motivasi.

\section{Kepribadian}

Kepribadian dalam hal ini merupakan watak seseorang untuk memiliki sifat-sifat sebagai wirausaha. Kepribadian untuk siap berwirausaha dapat ditinjau dari berorientasi, ketekunan, dan pengambilan risiko (toleransi risiko) yang dijelaskan sebagai berikut: aksi berorientasi ke masa depan, ketekunan, pengambilan risiko.

\section{Keterampilan wirausaha}

Keterampilan berwirausaha dalam hal ini merupakan ketrampilan seseorang untuk berwirausaha, keterampilan-keterampilan yang 
harus dimiliki dalam berwirausaha adalah keterampilan dalam kepemimpinan, keterampilan membangun jaringan, dan keterampilan persuasi.

\section{Motivasi}

Menurut Malayu (2003: 95), motivasi adalah pemberian daya gerak yang menciptakan kegairahan kerja seseorang, agar mereka mau bekerja sama, bekerja efektif dan terintegrasi dengan segala daya upayanya untuk mencapai kepuasan.

Dari beberapa pengertian mengenai kesiapan dan kewirausahaan, dapat dirumuskan bahwa kesiapan berwirausaha adalah keseluruhan kondisi seseorang yang membuatnya siap untuk memberi respon atau jawaban dalam kegiatan berwirausaha. Respon tersebut dipengaruhi oleh kondisi fisik, sikap mental, emosional, motivasi, tujuan, ketrampilan, dan pengetahuan. Dari uraian diatas, utuk siap dalam berwirausaha selain memiliki sikap mental yang kuat diperlukan beberapa faktor-faktor yang harus dipenuhi untuk mengisi indikator kesiapan berwirausaha. Indikator yang diperlukan adalah memiliki orientasi kedepan agar kita dapat memiliki pandangan dan keinginan yang kuat untuk maju dan berkembang. Selain itu kemampuan pengambilan risiko terhadap tantangan dari pesaing, agar kita memiliki keberanian dalam bersaing tanpa takut mengalami kegagalan. Kreatifitas sangat penting diperlukan dalam berwirausaha, karena dengan adanya kreatifitas rasa ingin tahu yang tinggi dapat memunculkan ide-ide, sehingga terbuka dengan gagasan yang baru. Dan yang terakhir adalah ketrampilan berwirausaha, dalam hal ini kemampuan membangun jaringan berwirausaha dan kemampuan untuk mempengaruhi orang lain.

\section{Peranan Orang Tua}

Menurut Tony (2007: 120), lingkungan keluarga terutama orang tua akan memberikaan corak budaya, suasana rumah, pandangan hidup dan juga pola yang akan menentukan sikap, perilaku serta proses pendidikan terhadap anakanaknya. Hisrich, et.al (2008: 75-78) menjelaskan ada empat faktor yang mempengaruhi karakteristik wirausaha, yaitu education, personal value, age (dijelaskan tentang childhood family environment) and work history. Hal tersebut dapat dimaknai bahwa lingkungan keluarga semasa kecil dengan adanya peranan orang tua didalamnya dapat mempengaruhi terbentuknya jiwa wirausaha pada anak. Ini dapat dilihat dari anak nomor berapa, orang tua, pekerjaan dan status sosial.

Dukungan orang tua dapat menjadikan anaknya menjadi sikap berwirausaha pula. Dukungan orang tua sangat penting dalam pengampilan keputusan pemilihan karir dan kesiapan bagi anak. Penuturan beberapa pengusaha dalam Hisric (2008: 79), menyatakan bahwa semua dukungan keluarga yang saya terima merupakan kunci keberhasilan. Hal ini memperjelas bahwa dukungan keluarga sangat penting untuk menjadikan anaknya berhasil dalam berwirausaha. Peranan orang tua dalam hal ini sangat berperan penting untuk menunjang kesiapan berwirausaha. Dalam Undang-Undang No. 20 Tahun 2003 tentang Sistem Pendidikan Nasional pada Pasal 7 menjelaskan bahwa orang tua mempunyai peranan penting dalam satuan pendidikan dan memperoleh informasi tentang 
perkembangan pendidikan anaknya. Selain itu, dengan adanya peranan orang tua dapat mengembangkan pembentukan kepribadian anak yang berada pada ranah afektif seperti meningkatkan kreativitas, kecermatan, ketekunan, maupun dapat memberikan apresiasi kepada anaknya. Pembentukan kepribadian anak dapat diperoleh dari pengalaman masa lalu orangtua, inspirasi anak dari orangtua.

Menurut Krueger (Basu \& Virick, nd: 84) menyatakan bahwa siswa yang memiliki orangtua seorang pengusaha dan yang menerima pengetahuan kewirausahaan pada usia muda akan membentuk sikap dan persepsi mengenai self-efficacy akan kesiapan berwirausaha. Memiliki orang tua yang mandiri atau berbasis wirausaha, kemandirian dan fleksibilitas orang tua akan melekat pada pada diri anaknya sejak kecil. Orang tua yang bekerja sebagai wirausaha akan mendukung dan mendorong kemandirian, berprestasi, dan bertanggungjawab anaknya. Kemudian sikap kemandirian akan tumbuh dan mendorong untuk memiliki usaha sendiri. Peran orang tua dalam menumbuhkan jiwa kewirausahaan anak diantaranya dengan komunikasi yang kondusif di lingkungan keluarga, latihan tanggung jawab terhadap pekerjaan domestik, membuka dan membimbing bakat yang terpendam dari anak, latihan memimpin atau mengelola event yang terjadi di lingkungan rumah serta mendorong anak untuk aktif dalam kegiatan lingkungan sosialnya.

Peran orang tua tidak hanya berupa dalam pembentukan kepribadian anak agar kelak menjadi wirausahawan yang sukses. Modal juga merupakan salah satu peranan dari orangtua untuk meningkatkan motivasi anak untuk berwirausaha. Peranan orangtua terhadap dukungan modal dapat berupa financial (keuangan), alat maupun tempat berwirausaha dan investasi. Selain mengarahkan orangtua dapat anak untuk berwirausaha dengan membantu modal berupa keuangan, bisa juga didukung dalam bentuk prasarana atau tempat usaha. Modal berupa uang maupun tempat usaha tidak harus banyak dan dipaksakan, walaupun sedikit modal dapat sebagai bentuk dukungan terhadap anak untuk menjadi wirausaha.

\section{Ketrampilan Kejuruan Pengelolaan Usaha Jasa Boga}

Kata ketrampilan sama artinya dengan kata kecekatan. Terampil adalah kepandaian melakukan sesuatu pekerjaan dengan cepat dan benar (Soemarjadi, 1993: 2). Seseorang dapat dikatakan terampil jika orang tersebut dapat melakukan pekerjaannya dengan cepat tanpa ragu-ragu akan melakukan sebuah kesalahan. Jika orang tersebut benar melakukan pekerjaan akan tetapi bekerja secara lambat karena raguragu akan kebenaran suatu pekerjaan tersebut, maka orang tersebut belum dapat dikatakan terampil.

Salah satu bentuk latar belakang pendidikan adalah keterampilan atau keahlian yang dimiliki, baik yang didapat dari pendidikan sekolah maupun di luar sekolah. Keterampilan atau keahlian ynng dimaksud adalah yang mampu dimanfaatkan untuk hidup mandiri (independen), atau sering disebut dengan life skills. Istilah kecakapan hidup (life skills) diartikan sebagai kecakapan yang dimiliki seseorang untuk mau dan berani menghadapi problema hidup dan penghidupan secara wajar tanpa merasa tertekan, kemudian secara proaktif 
dan kreatif mencari serta menemukan solusi sehingga akhirnya mampu mengatasinya (Dirjen PLSP, Direktorat Tenaga Teknis, 2003) dalam Dadang. Sedangkan (Dikdasmen: 6), mengklasifikasikan pendidikan life skills menjadi dua, yaitu academic skill dan vocational skill. Keterampilan kejuruan (vocational skill) berperan langsung terhadap keterampilan atau kecakapan yang dimanfaatkan untuk hidup mandiri, oleh karenanya keterampilan kejuruan dapat dimaknakan sangat dekat dengan life skills.

Berdasarkan teori di atas mengenai hubungan pendidikan keterampilan dan kewirausahaan, maka dapat disimpulkan bahwa pendidikan keterampilan yang diperoleh dari luar maupun SMK dapat dijadikan pegangan untuk berwirausaha. Jika dilihat pada keterampilan kejuruan dengan kompetensi keahlian Jasa Boga saat ini, keterampilan berwirausaha dapat dilatih dengan keterampilan kejuruan pengelolaan Usaha Jasa Boga (UJB). Keterampilan ini selain menitik beratkan pada keterampilan kejuruan, juga mengembangkan jiwa berwirausaha pada siswanya. Pada keterampilan kejuruan pengelolaan UJB siswa diharapkan mampu mengelola keterampilan kejuruannya menjadi suatu usaha yang menghasilkan. Dalam silabus, keterampilan kejuruan yang diperoleh dari SMKN 6 Yogyakarta, siswa diharapkan mampu melakukan pengelolaan usaha jasa boga, dengan kompetensi yang harus dilakukan meliputi menjelaskan sistem usaha jasa boga, menghitung kalkulasi harga, menyiapkan makanan, dan mengorganisir operasi menjadi layak jual.

\section{Self Efficacy}

Konsep self-efficacy pertama kali dikemukakan oleh Bandura. Secara terminologi “self-efficacy is defined as people's beliefs about their capabilities to produce designated levels of performance that exercise influence over events that affect their lives" (Bandura, 1994: 71). Pengertian tersebut menjelaskan bahwa keyakinan terhadap kemampuan pribadi untuk merencanakan/mengorganisasi dan menyelesaikan/mengimplementasi suatu tindakan yang penting untuk mencapai tujuan dan hasil tertentu. Pengertian self-efficacy pada proximal personality variabel (Leon, 2007: 88) adalah keoptimisan mengenai self-belief untuk mengatasi bermacam-macam tuntutan yang sulit. Dalam hal ini, mem-percayai satu aksi, dan bertanggung jawab atas keberhasilan suatu hasil. Pajares (1997: 7) berpendapat, selfefficacy adalah penilaian seseorang terhadap kemampuan diri untuk mengorganisasikan dan melaksanakan langkah-langkah yang terarah untuk mencapai suatu tujuan.

$$
\text { Bandura (1986) dalam }
$$

http://www.workhealth.org/risk /rfbself.html memaparkan bahwa

self-efficacy expectations consist of three dimensions: magnitude, generality, and strength. Each of these dimensions implies different measurement procedures. Magnitude refers to the ordering of tasks by difficulty level. Generality concerns the extent to which efficacy expectations about a specific situation can be generalized to other situations. Finally, strength refers to a judgment of how certain one is of being able to succeed at a particular task.

Pemaparan Bandura tersebut menjelaskan bahwa pada individu terdiri dari tiga 
dimensi/komponen yang dapat digunakan untuk prosedur pengukuran. Ketiga dimensi tersebut dapat dijelaksan sebagai berikut: magnitude, strength, generality.

Dari beberapa uraian diatas mengenai self-efficacy dapat dirumuskan bahwa selfefficacy merupakan keyakinan seseorang terhadap kemampuan yang dimilikinya untuk mengorganisasikan dan bisa menampilkan perilaku yang efektif sehingga dapat menyelesaikan tugas tertentu dengan baik. Selfefficacy memiliki tiga dimensi penting yang dapat menjadi indikator dalam variabel selfefficacy. Ketiga indikator tersebut adalah magnitude atau dimensi yang berkaitan dengan kesulitan tugas di mana individu akan memilih tugas berdasarkan tingkat kesulitannya / kemampuannya, komponen generality atau keyakinan individu untuk menyelesaikan tugastugas tertentu dengan tuntas dan baik di mana tugas-tugas tersebut beragam dengan individu lainnya, dan komponen strength atau dimensi yang berkaitan dengan sejauh mana individu yakin / percaya diri dapat meyelesaikan tugas dengan sebaik-baiknya. Self-efficacy menjadi dasar dirinya melakukan usaha yang keras, bahkan ketika menemui hambatan sekalipun. Semakin tinggi kemampuan yang dimiliki maka akan semakin tinggi self-efficacy yang ada, begitu pula sebaliknya. Hal ini bisa terjadi karena semakin tinggi kemampuan yang dimiliki maka keyakinan untuk menyelesaikan tugas dengan baik juga semakin tinggi.

\section{METODE}

Jenis penelitian yang digunakan adalah $e x$ post facto. Penelitian telah dilaksanakan di SMK
Kompetensi Keahlian Jasa Boga di Daerah Istimewa Yogyakarta, yaitu siswa SMKN 4 Yogyakarta, SMKN 6 Yogyakarta, SMKN 1 Sewon, SMKN 2 Godean, SMKN 3 Wonosari, SMKN 1 Purwosari. Populasi berjumlah 460 orang dan sampel penelitian sebanyak 198 orang yang ditentukan dengan teknik proportional random sampling.

Variabel dalam penelitian ini terdiri dari tiga variabel bebas (independent variable). Variabel tersebut diberi simbol X1, X2 dan X3, yaitu Peranan orangtua, Ketrampilan Pengelolaan UJB, dan Self-efficacy. Variabel terikat (dependent variable) diberi simbol $\mathrm{Y}$ yaitu Kesiapan Berwirausaha. Data variabel Y, $\mathrm{X} 1$, dan X3 dikumpulkan menggunakan instrumen kuesioner (angket). Skala yang digunakan dalam mengukur aspek ini adalah skala Likert dengan empat alternatif jawaban. Data variabel X2 menggunakan dokumentasi yaitu nilai praktik pengelolaan UJB. Validitas angket digunakan teknik korelasi Product Moment dari Carl Pearson dan reliabilitasnya dianalisis menggunakan Alfa Cronbach's.

Teknik analisis data dalam penelitian ini menggunakan statistik deskriptif dan kecenderungan variabel. Kriteria kecenderungan yang digunakan dalam penelitian ini mengacu pada rumus yang dikembangkan Saifuddin Azwar (2011:108).

Dalam penelitian ini diuji empat asumsi, yaitu normalitas, linearitas heterokedastisitas, dan multikolinieritas. Pengujian hipotesis menggunakan analisis regresi ganda. Sebagai kriteria penerimaan dan penolakan digunakan tingkat signifikansi 5\%. Untuk mengetahui korelasi dan besarnya pengaruh masing-masing 
variabel bebas terhadap variabel terikat digunakan analisis regresi sederhana.

Tabel 1. Kecenderungan Variabel

\begin{tabular}{ccl}
\hline No & \multicolumn{1}{c}{ Skor Siswa } & Kategori \\
\hline \hline 1 & $\mathrm{X} \leq \mathrm{M}-1.5 \mathrm{SD}$ & $\begin{array}{l}\text { Sangat } \\
\text { Rendah }\end{array}$ \\
2 & $\mathrm{M}-1.5 \mathrm{SD}<\mathrm{X} \leq \mathrm{M}-0.5 \mathrm{SD}$ & Rendah \\
3 & $\mathrm{M}-0.5 \mathrm{SD}<\mathrm{X} \leq \mathrm{M}+0.5 \mathrm{SD}$ & Sedang \\
4 & $\mathrm{M}+0.5 \mathrm{SD}<\mathrm{X} \leq \mathrm{M}+1.5 \mathrm{SD}$ & Tinggi \\
& & Sangat \\
5 & $\mathrm{M}+1.5 \mathrm{SD}<\mathrm{X}$ & Tinggi \\
\hline
\end{tabular}

\section{HASIL PENELITIAN DAN PEMBAHASAN}

\section{Deskripsi Data}

Hasil perhitungan melalui statistik deskriptif kesiapan berwirausaha, peranan orangtua, ketrampilan pengelolaan UJB, dan self-efficacy Siswa SMK Kompetensi Keahlian Jasa Boga di Daerah Istimewa Yogyakarta disajikan pada Tabel 2 dan Gambar 1 berikut ini.

Tabel 2. Distribusi Kesiapan Berwirausaha (Y), Peranan Orangtua (X1), Ketrampilan Pengelolaan UJB (X2), dan Self-efficacy (X3) Siswa SMK Kompetensi Jasa Boga di DIY

\begin{tabular}{rlrrrrrrrrr}
\hline \multirow{2}{*}{ No } & \multirow{2}{*}{ Kategori } & \multicolumn{2}{c}{ Y } & \multicolumn{2}{c}{ X1 } & \multicolumn{2}{c}{ X2 } & \multicolumn{2}{c}{ X3 } \\
\cline { 3 - 10 } & & Frek. & \% & Frek. & \% & Frek. & \% & Frek. & \% \\
\hline \hline 1 & Sangat rendah & 11 & 5.6 & 10 & 5.1 & 62 & 31.3 & 9 & 4.5 \\
\hline 2 & Rendah & 61 & 30.8 & 61 & 30.8 & 80 & 40.4 & 47 & 23.7 \\
\hline 3 & Sedang & 61 & 30.8 & 39 & 19.7 & 34 & 17.2 & 92 & 46.5 \\
\hline 4 & Tinggi & 51 & 25.8 & 62 & 31.3 & 22 & 11.1 & 28 & 14.1 \\
\hline 5 & Sangat tinggi & 14 & 7.1 & 26 & 13.1 & 62 & 31.3 & 22 & 11.1 \\
\hline
\end{tabular}

Pada Tabel 2 Variabel kesiapan berwirausaha menunjukkan bahwa terdapat 5,6 \% (11 siswa) berada pada kategori sangat rendah, 30,8\% (61 siswa) berada pada kategori rendah; 30,8 \% (61 siswa) berada pada kategori sedang; $25,8 \%$ (51 siswa) berada pada kategori tinggi dan 7,1\% (14 siswa) berada pada kategori sangat tinggi. Variabel peranan orangtua menunjukkan bahwa terdapat $5,1 \%$ (10 siswa) berada pada kategori sangat rendah, 30,8 \% (61 siswa) berada pada kategori rendah dan 19,7\% (39 siswa) berada pada kategori sedang; 31,3\% (62 siswa) berada pada kategori tinggi dan 13,1 $\%$ (26 siswa) berada pada kategori sangat tinggi.
Variabel ketrampilan pengelolaan UJB menunjukkan bahwa terdapat 31,3\% (62 siswa) berada pada kategori rendah; 40,4 \% (80 siswa) berada pada kategori sedang; 17,2\% (34 siswa) berada pada kategori tinggi dan 11,1 \% (22 siswa) berada pada kategori sangat tinggi. Variabel self-efficacy menunjukkan bahwa terdapat $4,5 \%$ (9 siswa) berada pada kategori sangat rendah, 23,7 \% (47 siswa) berada pada kategori rendah; 46,5 \% (92 siswa) berada pada kategori sedang; $14,1 \%$ (28 siswa) berada pada kategori tinggi dan $11,1 \%$ (22 siswa) berada pada kategori sangat tinggi. 


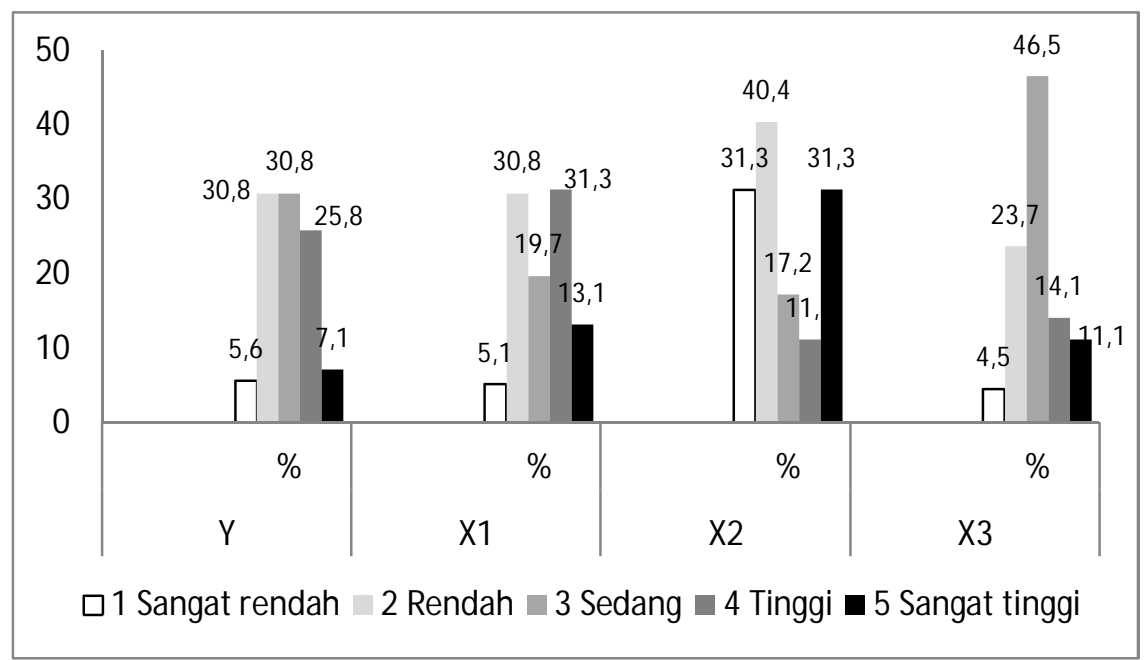

Gambar 1. Distribusi Kesiapan Berwirausaha (Y), Peranan Orangtua (X1), Ketrampilan Pengelolaan UJB (X2), dan Self-efficacy (X3) Siswa SMK Kompetensi Jasa Boga di DIY

Dari Gambar 1 dapat disimpulkan bahwa variabel kesiapan berwirausaha dengan kategori tinggi sebesar 25,8\% (51 siswa). Untuk variabel peranan orangtua dengan kategori tinggi sebesar $31,3 \%$ (62 siswa). Sedangkan variabel ketrampilan pengelolaan UJB dengan kategori tinggi sebesar 17,2 \% (34 siswa). Dan variabel self-efficacy dengan kategori tinggi sebesar 14,1 $\%$ (28 siswa).

\begin{abstract}
Analisis Data
Uji t ini akan dilakukan untuk melihat ada tidaknya peranan orangtua, ketrampilan pengelolaan UJB dan self-efficacy terhadap kesiapan berwirausaha secara parsial. Hasil uji hipotesis parsial dapat dilihat pada tabel di bawah ini.
\end{abstract}

Tabel 3. Hasil Uji Hipotesis Parsial (Uji t)

Coefficients $^{\mathrm{a}}$

\begin{tabular}{llccccc}
\hline \hline \multirow{2}{*}{ Model } & \multicolumn{7}{c}{ Unstandardized Coefficients } & $\begin{array}{c}\text { Standardized } \\
\text { Coefficients }\end{array}$ & & \\
\cline { 2 - 4 } & & $\mathrm{B}$ & Std. Error & Beta & $\mathrm{t}$ & Sig. \\
\hline \hline 1 & (Constant) & 27,451 & 3,854 & & 7,123 & 0,000 \\
& X1 & 0,655 &, 047 & 0,707 & 13,988 & 0,000 \\
\hline 2 & (Constant) & 20,909 & 4,025 & & 5,194 & 0,000 \\
& X1 & 0,445 & 0,068 & 0,480 & 6,563 & 0,000 \\
& X2 & 0,297 & 0,072 & 0,303 & 4,149 & 0,000 \\
\hline 3 & (Constant) & 15,157 & 4,496 & & 3,371 & 0,001 \\
& X1 & 0,374 & 0,072 & 0,404 & 5,229 & 0,000 \\
& X2 & 0,256 & 0,072 & 0,261 & 3,550 & 0,000 \\
& X3 & 0,191 & 0,071 & 0,170 & 2,706 & 0,007 \\
\hline
\end{tabular}

a. Dependent Variable: Y 
Berdasarkan tabel 3 dapat diketahui bahwa nilai sig $<5 \%$ untuk semua variabel, maka dapat disimpulkan bahwa:

\section{Uji Hipotesis Pertama}

Hipotesis pertama menyatakan bahwa peranan orangtua berpengaruh positif dan signifikan terhadap kesiapan berwirausaha pada siswa SMKN Kompetensi Keahlian Jasa Boga di DI Yogyakarta.

Dari tabel 3 dapat diketahui bahwa nilai koefisien $\mathrm{X}_{1}$ bernilai positif sebesar 0,374 dan memiliki nilai sig 0,000 yang menunjukkan bahwa variabel peranan orangtua memiliki hubungan yang positif dan siginifikan terhadap kesiapan berwirausaha pada siswa SMKN Kompetensi Keahlian Jasa Boga di DI Yogyakarta. Nilai koefisien $\left(\mathrm{X}_{1}\right)$ sebesar 0,374 juga memiliki arti, jika nilai peranan orangtua meningkat satu poin maka nilai kesiapan berwirausaha akan meningkat sebesar 0,374 poin dengan asumsi bahwa $X_{2}, X_{3}$ adalah tetap. Sehingga hipotesis pertama diterima.

\section{Uji Hipotesis Kedua}

Hipotesis kedua menyatakan bahwa ketrampilan pengelolaan UJB berpengaruh positif dan signifikan terhadap kesiapan berwirausaha pada siswa SMKN Kompetensi Keahlian Jasa Boga di DI Yogyakarta.

Dari tabel 3 dapat diketahui bahwa nilai koefisien $\mathrm{X}_{2}$ bernilai positif sebesar 0,256 dan memiliki nilai sig 0,000 yang menunjukkan bahwa variabel ketrampilan pengelolaan UJB memiliki hubungan yang positif dan siginifikan terhadap kesiapan berwirausaha pada siswa SMKN Kompetensi Keahlian Jasa Boga di DI Yogyakarta. Nilai koefisien $\left(\mathrm{X}_{2}\right)$ sebesar 0,256 juga memiliki arti, jika nilai ketrampilan pengelolaan UJB meningkat satu poin maka nilai kesiapan berwirausaha akan meningkat sebesar 0,256 poin dengan asumsi bahwa $X_{1}, X_{3}$ adalah tetap. Sehingga hipotesis kedua diterima.

\section{Uji Hipotesis Ketiga}

Hipotesis ketiga menyatakan bahwa selfefficacy berpengaruh positif dan signifikan terhadap kesiapan berwirausaha pada siswa SMKN Kompetensi Keahlian Jasa Boga di DI Yogyakarta.

Dari tabel 3 dapat diketahui bahwa nilai koefisien $X_{3}$ bernilai positif sebesar 0,191 dan memiliki nilai sig 0,007 yang menunjukkan bahwa variabel self-efficacy memiliki hubungan yang positif dan siginifikan terhadap kesiapan berwirausaha pada siswa SMKN Kompetensi Keahlian Jasa Boga di DI Yogyakarta. Nilai koefisien $\left(\mathrm{X}_{3}\right)$ sebesar 0,191 juga memiliki arti, jika nilai self-efficacy meningkat satu poin maka nilai kesiapan berwirausaha akan meningkat sebesar 0,191 poin dengan asumsi bahwa $\mathrm{X}_{1}, \mathrm{X}_{2}$ adalah tetap. Sehingga hipotesis ketiga diterima.

\section{Uji Hipotesis Keempat}

Hipotesis keempat menyatakan bahwa variabel peranan orangtua, ketrampilan pengelolaan UJB dan self-efficacy secara simultan berpengaruh positif dan signifikan terhadap kesiapan berwirausaha pada siswa SMKN Kompetensi Keahlian Jasa Boga di DI Yogyakarta.

Pada tabel 4 ditemukan bahwa nilai $\mathrm{F}$ sebesar 81,275 dengan nilai sig 0,000. Hal ini menunjukkan bahwa variabel peranan orangtua, ketrampilan pengelolaan UJB dan self-efficacy secara bersama-sama memiliki pengaruh positif dan signifikan terhadap terhadap kesiapan berwirausaha pada siswa SMKN Kompetensi 
Keahlian Jasa Boga di DI Yogyakarta. Sehingga hipotesis keempat diterima.

Tabel 4. Hasil Uji Hipotesis Simultan (Uji F)

\begin{tabular}{llrrrrr}
\multicolumn{7}{c}{ ANOVA $^{\mathbf{d}}$} \\
\hline \hline Model & Sum of Squares & Df & Mean Square & \multicolumn{1}{c}{ F } & Sig. \\
\hline \hline 1 & Regression & 4894,096 & 1 & 4894,096 & 195,664 & $0,000^{\text {a }}$ \\
& Residual & 4902,490 & 196 & 25,013 & & \\
& Total & 9796,586 & 197 & & & \\
\hline 2 & Regression & 5291,852 & 2 & 2645,926 & 114,536 & $0,000^{\text {b }}$ \\
& Residual & 4504,734 & 195 & 23,101 & & \\
& Total & 9796,586 & 197 & & & \\
\hline 3 & Regression & 5455,729 & 3 & 1818,576 & 81,275 & $0,000^{c}$ \\
& Residual & 4340,857 & 194 & 22,376 & & \\
& Total & 9796,586 & 197 & & & \\
\hline
\end{tabular}

a. Predictors: (Constant), X1

b. Predictors: (Constant), X1, X2

c. Predictors: (Constant), X1, X2, X3

d. Dependent Variable: Y

Tabel 5. Rangkuman Hasil Analisis Regresi Ganda

Model Summary

\begin{tabular}{ccrrr}
\hline \hline Model & R & $\begin{array}{c}\text { R } \\
\text { Square }\end{array}$ & $\begin{array}{c}\text { Adjusted R } \\
\text { Square }\end{array}$ & $\begin{array}{l}\text { Std. Error of } \\
\text { the Estimate }\end{array}$ \\
\hline \hline 1 & $0,707^{\mathrm{a}}$ & 0,500 & 0,497 & 5,00127 \\
\hline 2 & $0,735^{\mathrm{b}}$ & 0,540 & 0,535 & 4,80637 \\
\hline 3 & $0,746^{\mathrm{c}}$ & 0,557 & 0,550 & 4,73028
\end{tabular}

a. Predictors: (Constant), X1

b. Predictors: (Constant), X1, X2

c. Predictors: (Constant), X1, X2, X3

Nilai Adjusted $\mathrm{R}^{2}$ yang ditunjukkan pada tabel 5 sebesar 0,550 menerangkan bahwa variabel peranan orangtua, ketrampilan pengelolaan UJB dan self-efficacy mampu menjelaskan tentang variabel independent yang memberikan sumbangan efektif sebesar 55\% terhadap variabel kesiapan berwirausaha.
Sedangkan $45 \%$ kesiapan berwirausaha dipengaruhi oleh faktor-faktor selain ketiga variabel tersebut.

\section{PEMBAHASAN}

Berdasarkan uji hipotesis ditemukan bahwa seluruh variabel independent memiliki pengaruh positif dan signifikan terhadap kesiapan berwirausaha. Hal ini menunjukkan bahwa untuk meningkatkan kesiapan berwirausaha siswa, orangtua diharapkan berperan penting dalam meningkatkan jiwa berwirausaha, kemandirian, tanggung jawab, maupun motivasi. Berdasarkan uji statitik yang dilakukan pada penelitian ini, menunjukkan bahwa penelitian ini juga selaras dengan penelitian yang dilakukan oleh Anastasia, O.K (2007), dan Yuswati, I (2007) yang menemukan bahwa peranan keluarga / peranan orangtua 
memberikan pengaruh yang positif terhadap kesiapan berwirausaha.

Selain itu, ketrampilan yang diteliti adalah ketrampilan dalam kompetensi keahlian jasa boga, maka penelitian yang dilakukan menyangkut pada ketrampilan pengelolaan UJB. Pengelolaan UJB selain meningkatkan ketrampilan memasak pada siswa juga berperan dalam meningkatkan ketrampilan berwirausaha pada siswa. Ketrampilan berwirausaha dalam hal ini dititik beratkan pada pengelolaan catering maupun restaurant dikarenakan ketrampilan berwirausaha pada kompetensi keahlian jasa boga. Ketrampilan tersebut adalah menjelaskan sistem usaha jasa boga, menghitung kalkulasi harga, menyiapkan makanan, dan mengorganisir operasi menjadi layak jual.

Sedangkan dalam proses pembelajaran guru sebaiknya berupaya untuk menanamkan nilai-nilai self efficacy selama proses pembelajaran berlangsung untuk meningkatkan rasa percaya diri sesuai dengan kompetensinya untuk mendukung keberhasilan yang diraih. Berdasarkan uji statitik yang dilakukan pada penelitian ini, menunjukkan bahwa penelitian ini juga selaras dengan penelitian yang dilakukan oleh Caecilia, V. S (2012) yang menemukan bahwa self-efficacy memberikan pengaruh yang positif terhadap intensi berwirausaha berwirausaha. Self-efficacy mampu memberikan rasa percaya diri dan keyakinan akan kemampuan yang dimiliki dan menjadi modal yang penting dalam memulai suatu usaha. Oleh karena itu karena self efficacy sangat berguna dalam mendukung kewirausahaan di masa mendatang jika para siswa memiliki kesiapan untuk berwirausaha dikemudian hari.

\section{KESIMPULAN}

Berdasarkan hasil analisis data dan pembahasan, dapat disimpulkan:

1. Terdapat pengaruh yang positif antara peranan orang tua terhadap kesiapan berwirausaha siswa SMKN Kompetensi Keahlian Jasa Boga. Dalam hal ini, peranan orang tua merupakan faktor yang paling dominan mempengaruhi kesiapan berwirausaha.

2. Terdapat pengaruh yang positif antara ketrampilan kejuruan Pengelolaan Usaha Jasa Boga terhadap kesiapan berwirausaha siswa SMKN Kompetensi Keahlian Jasa Boga.

3. Terdapat pengaruh yang positif antara selfefficacy terhadap kesiapan berwirausaha siswa SMKN Kompetensi Keahlian Jasa Boga.

4. Terdapat pengaruh yang positif antara peranan orang tua, ketrampilan kejuruan Pengelolaan Usaha Jasa Boga, dan selfefficacy secara bersama-sama terhadap kesiapan berwirausaha siswa SMKN Kompetensi Keahlian Jasa Boga.

\section{DAFTAR PUSTAKA}

Anastasia Onik Kartikaningsih. 2007. Kesiapan berwirausaha siswa tingkat III SMK kelompok bisnis dan manajemen program keahlian penjualan di Kabupaten Gunungkidul, Daerah Istimewa Yogyakarta. Tesis magister, tidak diterbitkan, Universitas Negeri Yogyakarta, Yogyakarta.

Badan Pusat Statistik. 2011. Perkembangan beberapa indikator utama sosial-ekonomi Indonesia Agustus 2011. Jakarta: BPS, Katalog BPS: 3101015.

Bandura, A. 1994. Self-efficacy. Dalam V. S. Ramachaudran (Ed..), Encyclopedia of 
Human Behavior, (4, 71-81). New York: Academic Press.

Basu, A. \& Virick, M. (nd). Assesing entrepreneurial intentions amongs students: A comparative study. San Jose State University. Diambil pada tanggal 29 Januari 2012 jam 16:45 WIB, dari http://nciia.org/conf08/assets/pub/

basu2.pdf.

Caecilia, V.S. 2012. Faktor-faktor yang mempengaruhi intensi berwirausaha siswa SMK program studi keahlian teknik otomotif di kabupaten TabalongKalimantan Selatan. Tesis magister, tidak diterbitkan, Universitas Negeri Yogyakarta, Yogyakarta.

Fu'adz, Al-Gharuty. 2 Februari 2009. Inovasi kurikulum pendidikan kejuruan 84-2004. Diambil pada tanggal 22 Juni 2012 jam 17:49 WIB, dari http://adzelgar.wordpress.com/2009/02/02 /inovasi-kurikulum-pendidikan-kejuruan84-2004/

Hisrich, R.D., Peters, M.P. \& Shepherd, D.A. 2008. Entrepreneurship ( $7^{\text {th }}$ ed). New York: McGraw-Hill.

Hisrich, R.D., Peters, M.P. \& Shepherd, D.A. 2008. Kewirausahaan (edisi 7). (Terjemahan Chriswan Sungkono \& Diana Angelica). New York: McGrawHill. (buku asli diterbitkan tahun 2008).

Léon, J.A.M., \& Gorgievski, M. 2007. Teaching psychology of entrepreneurship: research and education. Madrid: Universidad Nacional de Educación a Distancia.

Macke, D., \& Markley, D. June 2003. Readiness for entrepreneurship: Tools for energizing entrepreneurship. Missouri: Center for Rural Entrepreneurship, 1. Diambil pada tanggal 19 Oktober 2011 jam 10:54, dari http://www.ruraleship.org.

Marsono. 2010. Kesiapan berwirausaha mahasiswa pendidikan teknik mesin fakultas teknik universitas negeri Yogyakarta ditinjau dari pengetahuan kewirausahaan, dukungan keluarga, soft skills, dan prestasi belajar. Tesis magister, tidak diterbitkan, Universitas Negeri Yogyakarta, Yogyakarta.

Meredith, G.C., et al. 2005. Kewirausahaan teori dan praktek (Cetakan 8). (Terjemahan
Andre Asparsayogi \& Djarot Suseno). Geneva: International Labour Organization.

Mery, Citra. (nd). Mendorong pilihan karir berwirausaha pada mahasiswa guna mengentaskan pengangguran terdidik di Indonesia. Diambil pada tanggal 19 Oktober 2011 jam 11: 17 WIB, dari http://pustaka.unpad.ac.id/wp-

content/uploads/2010/06/mendorong_pili han karir berwirausaha.pdf.

Muller, Ken. 2010. Gauge your entrepreneurial readiness - With an entrepreneur test. Article Business Entrepreneurialism. Diambil pada tanggal 24 Mei 2012 jam 15: 08 WIB, dari http://ezinearticles.com/?Gauge-YourEntrepreneurial-Readiness---With-anEntrepreneur-Test\&id=3875638

Pajares, F. 1997. Current directions in selfefficacy research. Dalam Maehr, M \& Pntrich, P. R (Eds.), Advances in motivation and achievement (10, 1-49). Greenwich: JAI Press. Diambil pada tanggal 18 Januari 2012 jam 11:09, dari http://www.des.emory/mfp/BanEncy.ht ml.

Slameto. 2010. Belajar dan faktor-faktor yang mempengaruhinya (Cetakan 5). Jakarta: Rineka Cipta.

Soemarjadi, Muzni Ramanto \& Wikdati Zahri. (1993). Pendidikan ketrampilan. Jakarta: Depdikbud.

Tony Wijaya. 2007. Hubungan adversity intelligence dengan intensi berwirausaha. Jurnal Manajemen dan Kewirausahaan, 9, 2, 117-127. Diambil pada tanggal 28 Mei 2012 jam 20:29 WIB, dari http://puslit2.petra.ac.id/ejournal/index.p hp/man/article/viewFile/16784/16764

Wasty Soemanto. 1999. Pendidikan wiraswata: Sekuncup ide operasional (Cetakan ke 6). Jakarta: Bumi Aksara.

Wasty Soemanto. (2006). Psikologi pendidikan: Landasan kerja pemimpin pendidikan (Cetakan ke 5). Jakarta: Rineka Cipta. 